\title{
Thermal Preferences and Distribution of Northern Michigan Crayfishes
}

\author{
Troy A. Keller ${ }^{1,2, *}$ and Brian A. Hazlett ${ }^{3}$
}

\begin{abstract}
Crayfishes function as both ecosystem engineers and keystone species, and they serve as the trophic linkage between benthic organisms and fish predators. Because crayfish behavior, physiology, and growth are controlled by temperature, thermal differences among habitats may have important implications for crayfishes and the ecosystems they inhabit. To investigate the association between crayfish and temperature, we measured thermal preferences of 3 crayfish species in lab experiments (2007), recorded summer water temperatures at 9 sites (July 1-August 9 , 2008), and trapped crayfishes at these same sites in northern Michigan. Orconectes rusticus (non-indigenous) preferred nearly $1{ }^{\circ} \mathrm{C}$ warmer water $\left(\approx 22{ }^{\circ} \mathrm{C}\right)$ than $\mathrm{Or}$ conectes virilis and Orconectes propinquus. Crayfishes inhabited sites with similar temperatures. These sites had average summer temperatures ranging from $21-23{ }^{\circ} \mathrm{C}$. Sites without crayfish were on average $7^{\circ} \mathrm{C}$ colder than sites with crayfish. Thus, crayfish thermal preferences were closely correlated with average summer water temperatures across aquatic habitats.
\end{abstract}

\section{Introduction}

Crayfishes are a diverse taxonomic group of freshwater invertebrates that have the center of their diversity located in North America (Taylor et al. 1996). These large and abundant invertebrates are important ecosystem engineers (Statzner et al. 2000) and can function as keystone species (Creed 1994). Because of their role as prey of stream fishes, they function as a trophic link between benthic communities and predatory fishes (Rabeni 1992). Their important ecological role provides impetus for investigating factors (e.g., temperature) that regulate their geographic distribution. Crayfishes, like other eurythermal freshwater invertebrates, have physiological adaptations that enable them to tolerate a broad range of temperatures. Temperature regulates crayfish physiology (Whiteley et al. 1997), behavior (Crawshaw 1983), and growth (Wetzel and Brown 1993), and it may alter crayfish productivity and geographic distribution (Momot 1984).

Lotic water temperatures are controlled by atmospheric conditions, topography, discharge, and stream-bed exchange (Caissie 2006). Vannote et al. (1980) hypothesized that local gradients in rivers (e.g., temperature and light) could influence the biotic communities that live in different portions

${ }^{1}$ University of Michigan Biological Station, 9133 East State Street, Pellston, MI 49769. ${ }^{2}$ Current address - Environmental Science Program, Columbus State University, 4225 University Avenue, Columbus, GA 31907. ${ }^{3}$ Department of Ecology and Evolutionary Biology, University of Michigan, Ann Arbor, MI 48109. "Corresponding author-keller_troy@colstate.edu. 
of these ecosystems. Gradients in thermal conditions have been shown to contribute to changes in fish (Taniguchi et al. 1998) and insect (Vannote and Sweeney 1980) assemblages; similar results could be expected for crayfishes. If true, local habitat-specific differences in temperature could have important implications for crayfishes. In northern Michigan, neighboring streams can have statistically significant differences in their annual temperature fluctuations. For example, the Maple River fluctuated more than $25^{\circ} \mathrm{C}$ during 2008 , while nearby Carp Creek ranged only $9{ }^{\circ} \mathrm{C}$ during the same period (T.A. Keller, unpubl. data). The degree to which these habitat-specific differences in temperature affect crayfish assemblages remains unknown. A review of the crayfish literature confirms that a paucity of studies have evaluated how crayfish temperature preferences relate to distributions of crayfishes among natural environments (Lodge and Hill 1994).

There are three common, surface-water-dwelling crayfishes in northern, lower Michigan. All have extensive geographic distributions that span the northern portion of the United States and southern Canada (Taylor et al. 1996). Orconectes propinquus Girard (Northern Clearwater Crayfish) and Orconectes virilis Hagan (Virile Crayfish) have long been reported as being widespread in Michigan (Creaser 1931) and are designated as native to our study region. Orconectes rusticus Girard (Rusty Crayfish) has only been observed in northern, lower Michigan since the late 1980s (B.A. Hazlett, unpubl. data). It was most likely introduced by fisherman from its native range in Ohio and Kentucky (Capelli 1982).

This study investigated the association between thermal preference, local temperature, and the geographic distribution of crayfishes. These data could provide insights into factors influencing the distributions of two native and one non-indigenous crayfish species. To study this association, we conducted laboratory thermal preference experiments and surveyed crayfish and water temperature in northern Michigan aquatic ecosystems. We hypothesized 1) that the mid-latitude origins of $O$. rusticus predispose it to a preference for warmer water than $O$. virilis and $O$. propinquus, 2) that species-specific temperature preferences measured in the lab would correlate with the temperatures measured at locations with high trapping success, and 3 ) that temperature influences the presence/absence of crayfishes generally.

\section{Methods}

\section{Thermal preference study}

We studied the temperature preferences of O. rusticus, O. virilis, and $O$. propinquus at the University of Michigan Biological Station's Stockard Lakeside Laboratory between July 4 and August 12, 2007. We maintained crayfish in a 113-L aquarium (91 cm long, $33 \mathrm{~cm}$ wide, $41 \mathrm{~cm}$ deep), for at least 1-2 days (Hazlett 1994) at room temperature (thermostat set to $20^{\circ} \mathrm{C}$ ) to maintain animals in uniform, laboratory conditions prior to testing. We 
collected O. rusticus from Burt Lake $(n=27)$, Mullett Creek $(n=5)$, and Carp River $(n=7) ; O$. virilis from Burt Lake $(n=27)$ and Maple River $(n=18)$; and O. propinquus from Douglas Lake $(n=15)$ and Maple River $(n=14)$. We used only adult-sized crayfish in the preference trials.

Crayfish temperature preferences were tested in three separate $38-\mathrm{L}$ temperature-controlled aquaria $(51 \mathrm{~cm}$ long, $25 \mathrm{~cm}$ wide, $31 \mathrm{~cm}$ deep). We placed a brick ( $27 \mathrm{~cm}$ long, $12 \mathrm{~cm}$ wide, $6.2 \mathrm{~cm}$ high) in the middle of each aquarium and set pieces of plexiglas ${ }^{\circledR}$ sloping down from the brick to the aquarium bottom on both sides. We filled the space below the plastic with sand. The plastic was roughened with sand paper to provide traction for the crayfish. We heated one end of each tank using a submersible heater and cooled the other using ice around the outside of the aquarium. This design kept the cooler, heavier water on one side of the aquarium and minimized vertical thermal stratification. By adjusting the heater settings and the quantity of ice used, we maintained the water temperature of the tank ends at $22{ }^{\circ} \mathrm{C}$ and $18{ }^{\circ} \mathrm{C}$ respectively. Temperatures were measured using thermometers placed in each end of the tanks. We chose this temperature range to match that recorded among sites in the Maple River.

Each aquarium was divided into five 10 -cm-long zones. The cooler end was designated as position 1. To ensure that all crayfish had the same test experience and to minimize disturbance to the thermal gradient, we carefully placed a single crayfish on the central brick and recorded the position of its cephalothorax every $5 \mathrm{~min}$ for $1 \mathrm{~h}$. Crayfish were placed in the tanks for 5 min prior to initiation of each trial. We alternated the cool and warm ends between each trial, changed the water, and randomized the order of testing (for all animals) to minimize the potential effects of other uncontrolled variables. Crayfish temperature preferences were analyzed using an analysis of covariance model (ANCOVA) that included terms for species, sex, location of capture (river versus lake), and all interaction terms. Carapace length was used as a covariate to control for potential size effects on crayfish temperature selection. Post-hoc comparisons were assessed using Tukey HSD, which corrects for experiment-wise error rates based on the number of comparisons.

We characterized the thermal gradient by recording temperature at all 5 positions in one of our experimental tanks using iButton ${ }^{\mathrm{TM}}$ recording devices (Maxim Integrated Products, Inc.). Data were collected in the absence of crayfish and recorded every min for $2 \mathrm{~h}$. To estimate the temperature at each position in the preference aquaria, we modeled the relationship between position and median temperature using a $2^{\text {nd }}$ order polynomial equation fitted using a least-squares procedure $\left(r^{2}=0.99\right)$.

\section{Field surveys}

We surveyed crayfish at 37 sites located within 8 rivers and 2 lakes in northern Michigan. The goal of the survey was to document the distribution 
of $O$. rusticus, $O$. virilis, and $O$. propinquus - the most common, surfacedwelling crayfishes in northern lower peninsula Michigan. Sites were selected to represent a range of habitats and for their accessibility (e.g., road crossings, bridges, lake shores). We sampled crayfish using 2 or more sardine-baited, modified Gee ${ }^{\mathrm{TM}}$ minnow traps $(42 \mathrm{~cm}$ long, 0.6- $\mathrm{cm}$ mesh, 4-cm opening) set for at least 1 night (June 19-Aug 4, 2007 and July 6-Aug $7,2008)$. In total, 284 traps were set during this study. To analyze the association between field temperatures and crayfish abundance, we analyzed a subset of trap results from 9 sites (see below) that were sampled in 2008 . We calculated the catch per unit effort from our trap data by dividing the number of crayfish captured by the number of traps set and the length of time in the water.

To quantify the temperature pattern among sites in northern Michigan, we deployed submersible temperature recording gauges (i.e., iButtons ${ }^{\mathrm{TM}}$ ) at 9 sites from July 1-August 9, 2008. Data loggers recorded temperature at each site every 4 hours. We placed loggers at 15 sites, but the data from 6 sites were lost when the gauges failed. We used the raw data to calculate the probability that readings would exceed a given temperature (i.e., exceedance plot) for all 9 sites. To examine the association between summer water temperature and crayfish, we compared the mean temperature between sites with and without crayfish (regardless of the species captured) using repeated measures ANOVA ( $n=9$ sites, $n=39$ daily temperatures). All crayfish species were grouped for this analysis, because this data set had a limited sample size.

\section{Results}

\section{Thermal preference study}

All 3 species selected positions within the testing apparatus that had temperatures ranging from $21-22{ }^{\circ} \mathrm{C}$. Despite this fact, thermal preferences differed significantly among species (ANCOVA $P<0.001$; Table 1). Orconectes rusticus chose positions within the aquaria with $\approx 1{ }^{\circ} \mathrm{C}$ warmer

Table 1. Results of multi-factorial analysis of covariance of crayfish position in the temperature choice aquaria. Total sample size $=113, r^{2}=0.35$.

\begin{tabular}{lccc} 
Factors & $\mathrm{df}$ & F-ratio & $P$-value \\
\hline Species & 2 & 13.1 & 0.000 \\
Source & 1 & 4.2 & 0.043 \\
Sex & 1 & 0.1 & 0.728 \\
Species*source & 1 & 4.0 & 0.022 \\
Source*sex & 1 & 0.5 & 0.498 \\
Species*sex & 2 & 2.2 & 0.113 \\
Species*source*sex & 2 & 2.9 & 0.062 \\
Size & 1 & 0.3 & 0.569 \\
Error & 100 & & \\
\hline
\end{tabular}


water than $\operatorname{did} O$. virilis or $O$. propinquus (Tukey $P<0.001$ for both comparisons). Orconectes virilis and $O$. propinquus selected positions within the testing tanks (Fig. 1) that had similar temperatures $\left(\approx 21{ }^{\circ} \mathrm{C}\right.$, Tukey $P=$ 0.5 ). Site of capture (i.e., lake versus stream) influenced thermal preferences (ANCOVA $P=0.04$; Table 1). However, only the average position of $O$. virilis collected from the lake was warmer than the position selected by crayfish from the stream (Tukey $P=0.002$; Fig. 1). Neither $O$. propinquus nor $O$. rusticus showed statistically significant habitat-specific thermal preferences (Tukey $P>0.2$ for both). Crayfish thermal preferences were similar regardless of the size or sex of the crayfish tested (ANCOVA $P>$ 0.5 for both; Table 1).

\section{Field surveys}

Our field survey of crayfishes among 37 sites using sardine-baited minnow traps yielded 526 individuals representing 4 crayfish species (Table 2).

Figure 1. Mean and standard error (bars) of tank position and estimated temperature $\left({ }^{\circ} \mathrm{C}\right)$ selected by lake (solid) and stream (open) Orconectes rusticus (lake $n=$ 27 , stream $n=12$ ), O. virilis (lake $n=27$, stream $n=$ 18 ), and $O$. propinquus (lake $n=$ 15 , stream $n=14$ ). Results are based on the average positions of crayfish

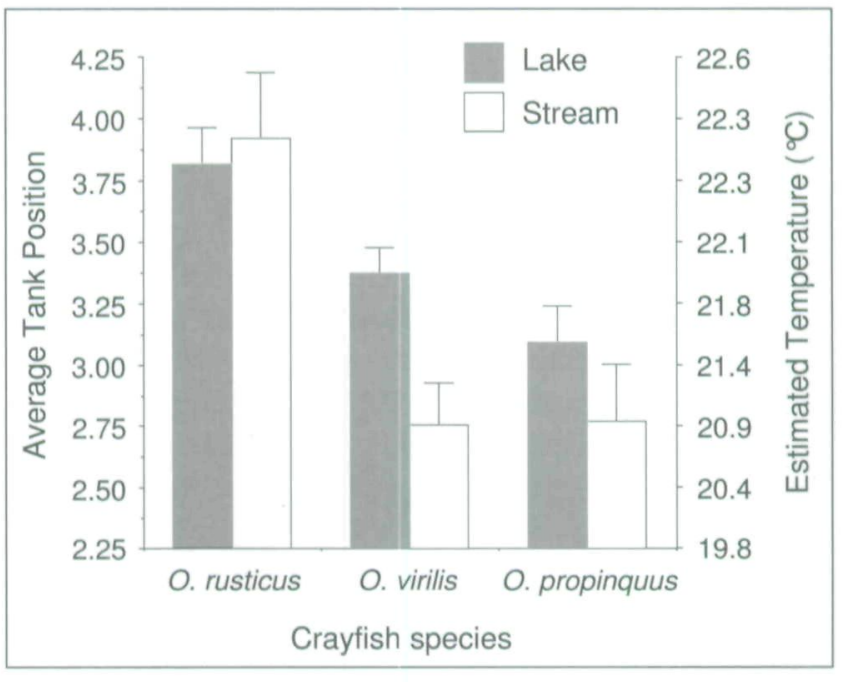
(1-5) within the preference tanks (1-hr trial). The second axis shows the modelestimated median temperatures at these positions $\left(r^{2}=0.99\right)$.

Table 2. Number of sites where crayfishes were collected (in total, as single species, with more than 1 species, and with Orconectes rusticus) and the number of crayfish collected during trap surveys in northern Michigan (2007 and 2008). The values in parentheses indicate the percent of total.

\begin{tabular}{lccccc} 
& \multicolumn{3}{c}{ \# of sites } & \# of crayfish \\
\cline { 2 - 4 } Species & Total & Single species & $\geq 2$ Species & With O. rusticus & captured \\
\hline O. rusticus & $11(31)$ & $5(14)$ & $6(17)$ & & $266(51)$ \\
O. virilis & $15(42)$ & $5(14)$ & $10(28)$ & $4(11)$ & $106(20)$ \\
O. propinquus & $11(31)$ & $2(6)$ & $9(25)$ & $3(8)$ & $154(29)$ \\
Total & 36 & & & & 526 \\
\hline
\end{tabular}


We excluded Cambarus diogenes Girard (Devil Crayfish) from further analysis since only 3 individuals were trapped during this study. Orconectes rusticus comprised $51 \%$ of all crayfish captured and was recorded at $31 \%$ of the sites sampled (Table 2). We trapped $O$. virilis at $42 \%$ of sites (Fig. 2), but numerically it composed only $20 \%$ of all crayfish collected (Table 2). Orconectes propinquus was captured at $31 \%$ of sites, and its abundance was intermediate at $29 \%$ of total crayfish collected. Both O. rusticus and $O$. virilis were trapped in Burt and Douglas lakes. We often found a monoculture of $O$. rusticus at river sites hydrologically connected to lakes containing this non-native species (Fig. 2). No crayfish were collected from $33 \%$ of the sites sampled. Co-occurrence among $O$. rusticus, $O$. virilis, and $O$. propinquus was common. We found 2 or more species present at $33 \%$ of sites sampled (Table 2). Orconectes rusticus co-occurred with O. propinquus and $O$. virilis at 3 and 4 sites respectively. Similarly $O$. virilis and $O$. propinquus

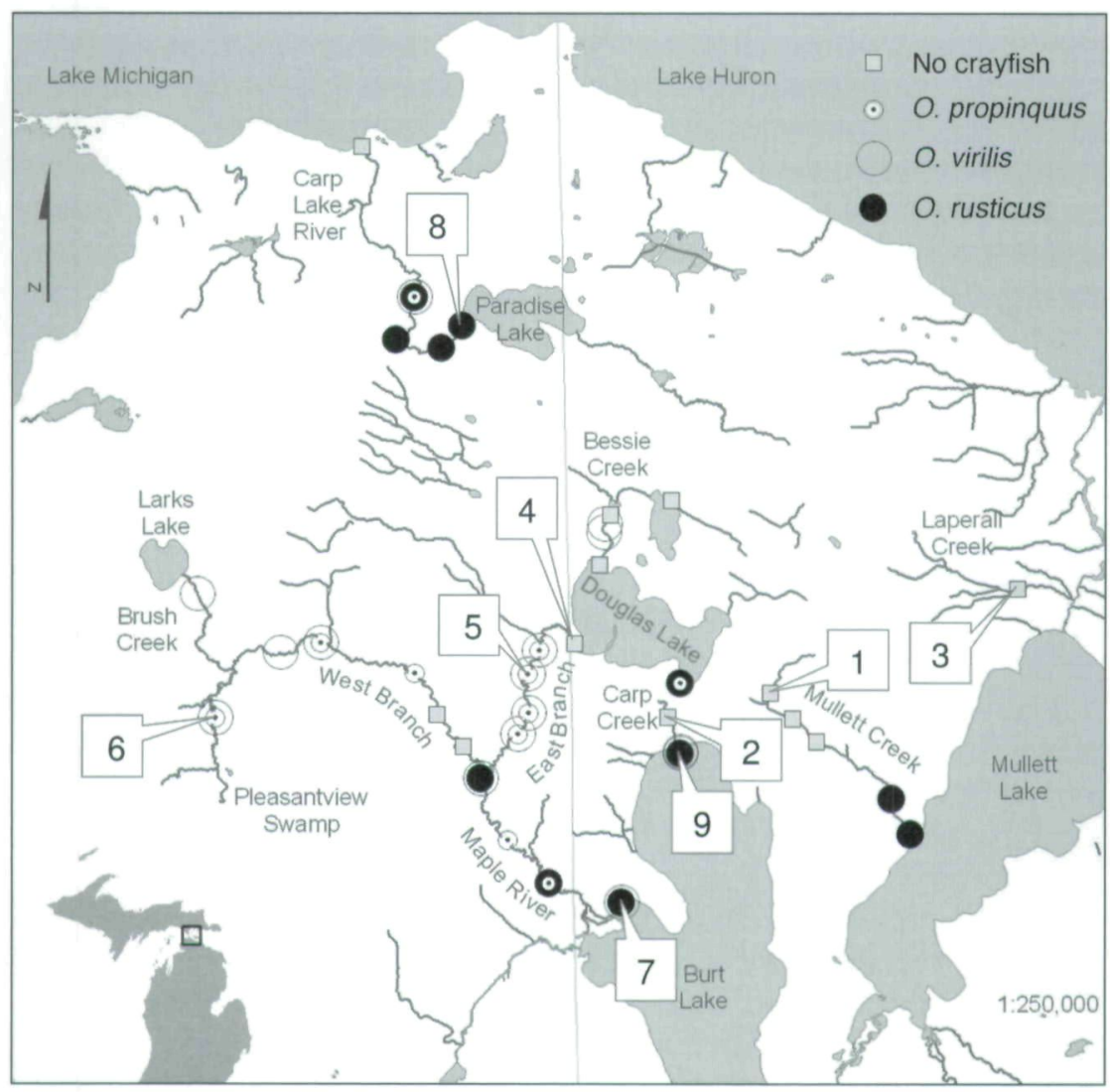

Figure 2. Map of the trapping sites for Orconectes rusticus (solid black circles), $O$. virilis (large open circle), and O. propinquus (open circle with dot). Gee ${ }^{\mathrm{TM}}$ minnow trap were baited using sardines at 37 sites in northern Michigan. Number labels indicate sites where temperature gauges and trapping occurred simultaneously during the summer of 2008 . 
co-occurred at 7 sites. Both $O$. virilis and $O$. rusticus occurred in isolation at 5 sites, whereas $O$. propinquus was the only crayfish species trapped at 2 sites (Table 2).

To characterize geographic variation in stream water temperature, we simultaneously deployed data loggers at 9 sites for 39 days. Temperature varied temporally among sites (Fig. 3). For example, sites 1-3 had little temperature variation compared to other sites. These same sites were colder and showed no temperature overlap with the other 6 sites despite their concurrent data record (Fig. 3).

To examine the association between crayfish abundance and the temperatures among natural habitats, we deployed traps at the 9 sites where we concurrently monitored daily temperatures (2008). Orconectes rusticus, $O$. virilis, and $O$. propinquus were collected from 3,4 , and 2 (respectively) of these sites (Table 3 ). Catch per unit effort for all three species ranged from 0-4 crayfish per trap day (Fig. 4). All three species were captured at

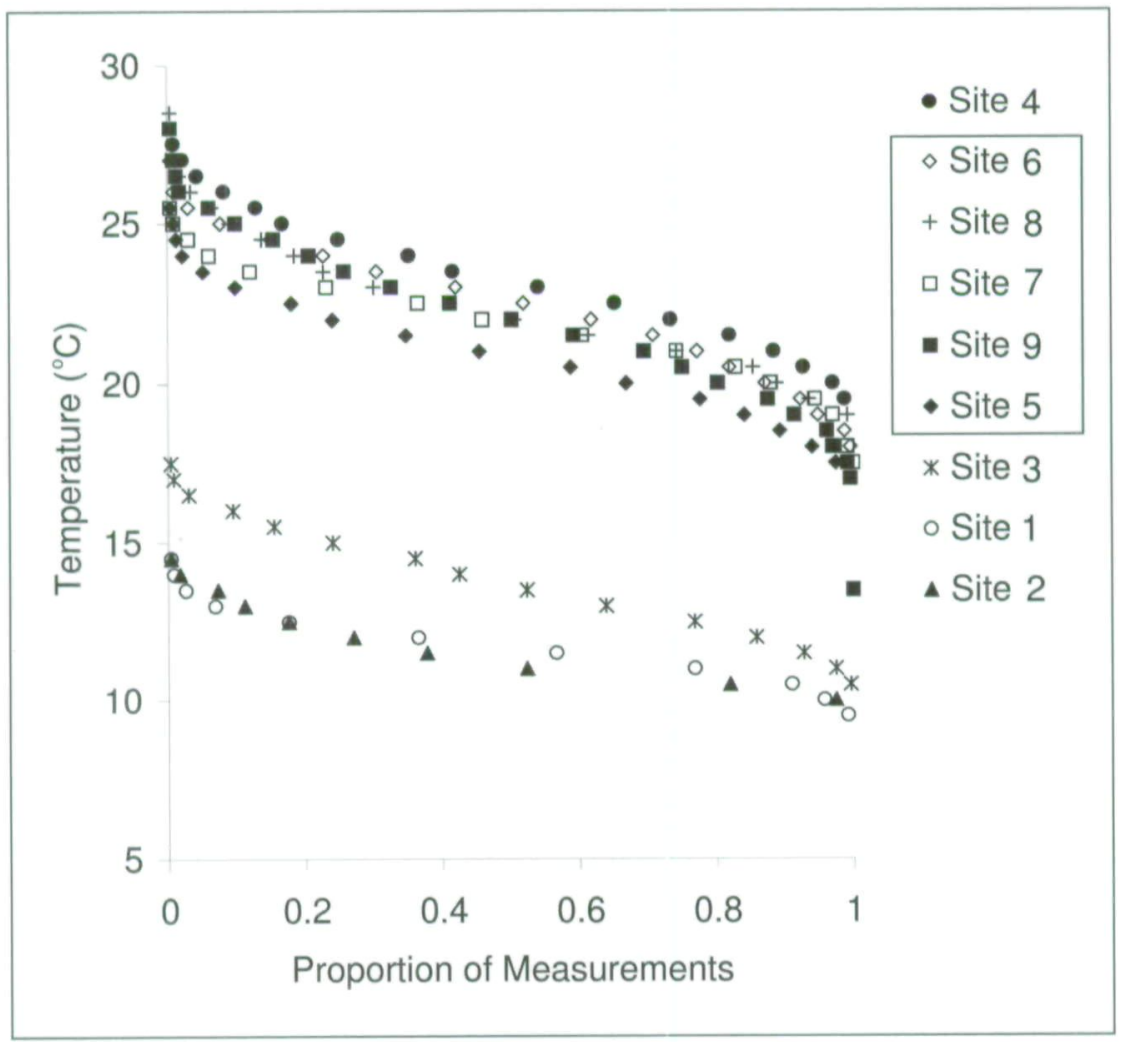

Figure 3. Probability of exceedance plotted against temperature for 9 sampling locations. An exceedance value of 1 indicates the lowest recorded temperature. Site numbers correspond to sampling locations (Fig. 2) where summer temperature was logged for 39 days in 2008 (Table 3). Crayfish were collected at sites contained in the rectangular box. 
sites with average temperatures ranging from 21.0 to $22.7^{\circ} \mathrm{C}$ (Fig. 4). The limited sample size of this dataset precludes a rigorous statistical analysis of temperature associations among individual species.

Because we only had a limited sample size $(n=9)$ and our results indicated little habitat-specific temperature differentiation among species (Fig. 4), we compared the temperatures of sites with and without crayfish (irrespective of species). Using the crayfish and temperature data from the 9 sites sampled in 2008, we found that sites without crayfish $(n=4)$ were significantly colder than those with crayfish $(n=5$, repeated measures ANOVA $P=0.026$; Table 3 ). No crayfish were collected from sites $1-4$. We never captured crayfish at site 4 despite the fact that it is located $10 \mathrm{~m}$

Table 3. Percentage of Orconectes rusticus (OR), O. virilis (OV), and O. propinquus (OP) collected at 9 sites (see Fig. 2) during the summer 2008 using sardine-baited Gee ${ }^{\mathrm{TM}}$ minnow traps. Effort indicates the number of traps multiplied by the time the traps were deployed. $n$ equals the total number of individuals trapped.

\begin{tabular}{|c|c|c|c|c|c|}
\hline \multirow[b]{2}{*}{ Site } & \multirow[b]{2}{*}{ Effort (traps*hr) } & \multirow[b]{2}{*}{$n$} & \multicolumn{3}{|c|}{$\%$} \\
\hline & & & OR & OV & OP \\
\hline 1 & 42.2 & 0 & & & - \\
\hline 2 & 37.3 & 0 & - & - & \\
\hline 3 & 43.8 & 0 & - & - & - \\
\hline 4 & 45.1 & 0 & - & & - \\
\hline 5 & 9675.0 & 108 & - & 25.0 & 75.0 \\
\hline 6 & 67.3 & 6 & - & 83.3 & 16.7 \\
\hline 7 & 77.9 & 16 & 75.0 & 25.0 & - \\
\hline 8 & 46.2 & 1 & 100.0 & - & - \\
\hline 9 & 40.3 & 12 & 66.7 & 33.3 & - \\
\hline
\end{tabular}

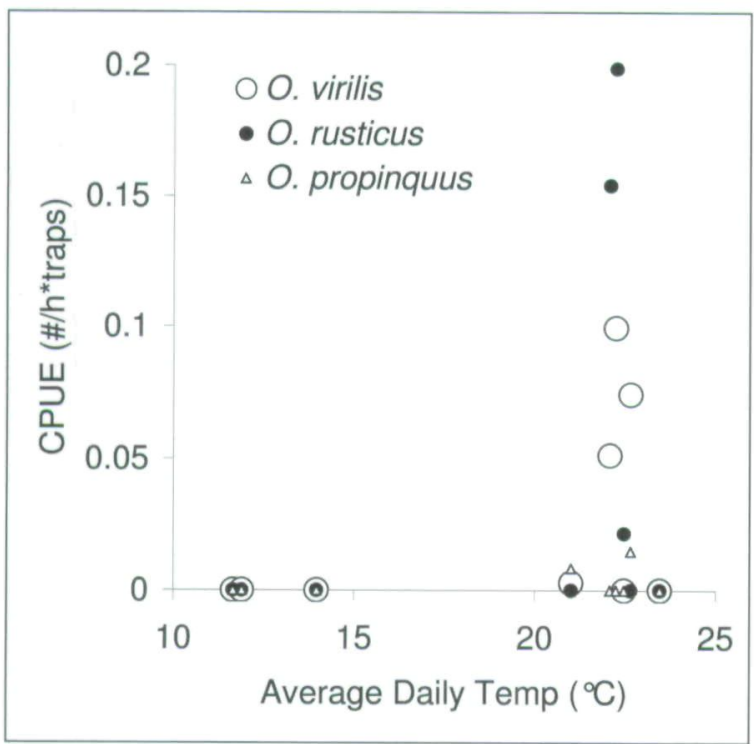

Figure 4. Catch per unit effort for 3 species-Orconectes virilis (open circles), O. rusticus (filled circles), and O. propinquus (open triangles)among 9 sites where temperature was recorded using submersible data loggers. Loggers recorded temperature $\left(0.5{ }^{\circ} \mathrm{C}\right.$ resolution) every 4 hours for 39 days during the summer 2008. 
downstream from Douglas Lake - a waterbody where we have collected all 3 species of crayfish. Furthermore, $1 \mathrm{~km}$ downstream of this site, the Maple River has populations of $O$. virilis and O. propinquus (Keller et al. 2005). Because site 4 draws warm epilimnetic water from Douglas Lake, its inclusion in the crayfish-absent group of sites increases that group's average temperature and variance. Thus the true temperature difference between sites with crayfish present and absent may prove to be even greater than reported here.

\section{Discussion}

This study tested and found support for the hypothesis that $O$. rusticus prefers warmer water temperatures than $O$. virilis and $O$. propinquus. However, the differences among species were relatively minor $\left(\approx 1{ }^{\circ} \mathrm{C}\right)$. While it is possible that the $4{ }^{\circ} \mathrm{C}$ temperature range of our test chambers could have constrained crayfish preferences, our results are consistent with other published results and show an association between lab-measured crayfish temperature preferences and temperatures of crayfish habitats. Thermal preferences reported for Orconectes immunis Hagan (Calico Crayfish) (18$22{ }^{\circ} \mathrm{C}$; Crawshaw 1974), Orconectes obscurus Hagen (Allegheny Crayfish) $\left(\approx 26^{\circ} \mathrm{C}\right.$; Hall et al. 1978$)$, O. rusticus $\left(22^{\circ} \mathrm{C}\right.$; Mundahl and Benton 1990$)$, O. virilis $\left(22-26^{\circ} \mathrm{C}\right.$; Peck 1985), and Astacus astacus L. (Noble Crayfish) $\left(\approx 18^{\circ} \mathrm{C}\right.$; Kivivuori 1994) indicate that crayfishes prefer temperatures from 18 to $26{ }^{\circ} \mathrm{C}$. Since crayfish growth improves as temperature increases (Wetzel and Brown 1993), crayfish that move to warmer habitats may grow larger and improve their ability to compete for shelter (Klocker and Strayer 2004), acquire mates (Berrill and Arsenault 1984), and avoid predators (Stein 1977). Mundahl and Benton (1990) hypothesized that adult $O$. rusticus select temperatures $\left(20-25^{\circ} \mathrm{C}\right)$ to maximize their survival, rather than their growth, to avoid problems caused by molting at high temperatures.

Thermal preferences may provide a behavioral mechanism to optimize metabolic demand by avoiding cellular hypoxia (high temperatures) or limitation of the aerobic capacity of mitochondria (low temperatures; Pörtner 2002). Literature reports for $O$. virilis $\left(0.017 \mathrm{~g} / \mathrm{g} / \mathrm{d}\right.$ at $26{ }^{\circ} \mathrm{C}$; Whitledge and Rabeni 2003), O. propinquus $\left(0.017 \mathrm{~g} / \mathrm{g} / \mathrm{d}\right.$ at $24{ }^{\circ} \mathrm{C}$; Spencer 1984), and O. rusticus $\left(0.013 \mathrm{~g} / \mathrm{g} / \mathrm{d}\right.$ at $25^{\circ} \mathrm{C}$; Eggleston and Lustick 1981) indicate that all 3 species have similar metabolic rates. These metabolic similarities may require similar temperature conditions and thermal preferences.

Crayfish acclimatize to water temperature both behaviorally (Hall et al. 1978, Taylor 1984) and physiologically (Claussen 1980, Layne et al. 1987). We expected that lake and stream temperatures would affect crayfish thermal preferences, as has been documented for O. obscurus (Hall et al. 1978). We found that $O$. virilis showed evidence that the habitat where it was captured influenced its thermal preference. Orconectes virilis from 
the lake showed a greater preference for warmer water than individuals captured in the stream, a pattern not detected for $O$. rusticus and $O$. propinquus. One possible explanation for this result could be that $O$. rusticus and $O$. propinquus adjusted their preferences very quickly during their lab acclimation period $(24-48 \mathrm{~h})$. Alternatively, these two species, like O. immunis (Crawshaw 1983), may have inherent thermal preferences that are not altered by environmental conditions.

We found that crayfish abundance varies among habitats with different temperatures; however, we had little data to evaluate the hypothesis that O. rusticus is disproportionately abundant at warm sites. All 3 species of crayfishes were most abundant at sites having summer temperatures ranging from $21-23{ }^{\circ} \mathrm{C}$, and no crayfish were captured or observed in streams with cold, stable summer temperature regimes. Additional trapping and nighttime visual surveys of these cool-water sites (1-3; Fig. 2) have yielded no evidence of the presence of crayfish (exoskeletons, burrows, etc). These cool water sites were not cold enough to cause acute crayfish mortality (Claussen 1980, Layne et al. 1987) given the fact that $O$. virilis can survive near freezing temperatures in northern climates (Aiken 1968). Knowing that $O$. virilis and $O$. immunis both fail to molt and grow when maintained at 10 ${ }^{\circ} \mathrm{C}$ in laboratory experiments (Wetzel and Brown 1993), it is possible that crayfishes require a critical period of warm conditions to sustain adequate growth before the onset of winter.

There is renewed scientific interest in quantifying geographic patterns in the physiological capabilities of species, characterizing the form of these patterns, and ultimately elucidating the mechanisms explaining them (Gaston et al. 2009). These generalizations about physiological tolerances may help explain the geographic distribution of crayfish species in northern Michigan. However, taxa-specific thermal maxima are unlikely to explain our findings. Orconectes rusticus and $O$. virilis have critical thermal maximums ranging from 33-40 ${ }^{\circ} \mathrm{C}$ (Claussen 1980). These temperatures exceed those recorded during this study. Furthermore, since $O$. rusticus can reduce its exposure to acute thermal stress by moving to new habitats when temperatures become extremely elevated (Mundahl 1989), it can endure episodic temperature extremes exceeding its thermal tolerance. The low abundance of crayfishes from the coldest sites may indicate that crayfish distributions are influenced by their thermal minimums. This explanation seems reasonable for crayfish living in northern latitudes $\left(>45^{\circ} \mathrm{N}\right)$; however, the evidence from the scientific literature supporting this explanation is limited. The thermal minimum of $O$. rusticus changes seasonally (Mundahl and Benton 1990) and declines to nearly $1{ }^{\circ} \mathrm{C}$ (Layne et al. 1987). Thus $O$. rusticus can alter its physiology seasonally and can tolerate near freezing temperatures. Data on the cold tolerance of $O$. virilis and $O$. propinquus are needed to assess whether physiological differences among species influence their geographic distribution. 
An additional pattern emerged when we analyzed the entire survey region (Fig. 3); O. rusticus was found in larger lakes and the adjourning streams. This pattern may indicate that $O$. rusticus occurs where humans have introduced them. People live near and fish in lakes and streams. When anglers released crayfish from their bait buckets they may have inadvertently transferred $O$. rusticus to new habitats (Capelli and Magnuson 1983, Olden et al. 2006). We collected O. rusticus in Mullett Creek, Maple River, and Carp River. These rivers are connected to O. rusticus populations from Mullett Lake, Paradise Lake, and Burt Lake (T.A. Keller, pers. observ.). Orconectes rusticus populations occur in the Maple River upstream of Burt Lake and downstream of a dam located at the confluence of the east and west branches. This dam may prevent $O$. rusticus from moving farther upstream. O. rusticus migrated around Trout Lake (Wisconsin) at a rate of $0.68 \mathrm{~km} / \mathrm{yr}$ (Wilson et al. 2004). This species might spread more slowly in streams that have dams and other barriers such as elevated culverts (Kerby et al. 2005). Our results are consistent with reports that $O$. rusticus is found at sites with extensive human activity (Capelli and Magnuson 1983) and appears to disperse to other water bodies that are connected hydrologically (Olden et al. 2006).

Our survey results indicate that $O$. rusticus has not completely displaced its congeners from streams and lakes in northern Michigan. At select locations (e.g., Carp River), this non-indigenous crayfish has spread into streams where it was not previously found and completely displaced established species (Hazlett 1985). In Burt and Douglas lakes, O. rusticus and its congeners have co-occurred for more than 20 years (B.A. Hazlett, unpubl. data). More data are needed to assess whether $O$. virilis will be completely displaced by O. rusticus in Burt and Douglas lakes. Despite its rapid dispersal and increasing proportional representation within the crayfish fauna, Olden et al. (2006) found that O. rusticus co-occurred regionally with $O$. virilis and $O$. propinquus in over $86 \%$ of watersheds examined. It is possible that environmental (e.g., temperature), spatial (e.g., dams), and temporal factors (e.g., time since introduction) enable regional co-occurrence among crayfishes as $O$. rusticus colonizes new habitats. Questions regarding what environmental conditions influence the geographic distribution of crayfish species should present an important focus of future research.

\section{Acknowledgments}

We thank Mouna DiBenedetto, Lisa Keller, and Danielle Stoermer for their assistance in collecting temperature data and crayfish. The comments of Lisa Keller and two anonymous reviewers improved the quality of the manuscript. Bob Vande Kopple and the University of Michigan Biological Station provided space and equipment necessary to complete this research. 


\section{Literature Cited}

Aiken, D.E. 1968. Crayfish Orconectes virilis survival in a region with severe winter conditions. Canadian Journal of Zoology 46:207-211.

Berrill, M., and M. Arsenault. 1984. The breeding behavior of a northern temperate orconectid crayfish, Orconectes rusticus. Animal Behaviour 32:333-339.

Caissie, D. 2006. The thermal regime of rivers: A review. Freshwater Biology 51:1389-1406.

Capelli, G.M. 1982. Displacement of northern Wisconsin crayfish by Orconectes rusticus (Girard). Limnology and Oceanography 27:741-745.

Capelli, G.M., and J.J. Magnuson. 1983. Morphoedaphic and biogeographic analysis of crayfish distribution in Northern Wisconsin. Journal of Crustacean Biology 3:548-564.

Claussen, D.L. 1980. Thermal acclimation in the crayfish, Orconectes rusticus and Orconectes virilis. Comparative Biochemistry and Physiology A 66:377-384.

Crawshaw, L.I. 1974. Temperature selection and activity in crayfish, Orconectes immunis. Journal of Comparative Physiology 95:315-322.

Crawshaw, L.I. 1983. Effects of thermal acclimation and starvation on temperature selection and activity in the crayfish, Orconectes immunis. Comparative Biochemistry and Physiology A 74:475-477.

Creaser, E.P. 1931. The Michigan decapod crustaceans. Papers of the Michigan Academy of Sciences, Arts, and Letters 13:257-276.

Creed, R.P. 1994. Direct and indirect effects of crayfish grazing in a stream community. Ecology 75:2091-2103.

Eggleston, P.M., and S.I. Lustick. 1981. The oxygen requirements of the crayfish, Orconectes rusticus. Ohio Journal of Science 81:92-94.

Gaston, K.J., S.L. Chown, P. Calosi, J. Bernardo, D.T. Bilton, A. Clarke, S. ClusellaTrullas, C.K. Ghalambor, M. Konarzewski, L.S. Peck, W.P. Porter, H.O. Pörtner, E.L. Rezende, P.M. Schulte, J.I. Spicer, J.H. Stillman, J.S. Terblanche, and M.V. Kleunen. 2009. Macrophysiology: A conceptual reunification. American Naturalist 174:595-612.

Hall, L.W., D.A. Cincotta, J.R. Stauffer, and C.H. Hocutt. 1978. Temperature preference of the crayfish Orconectes obscurus. Archives of Environmental Contamination and Toxicology 7:379-383.

Hazlett, B.A. 1985. Disturbance pheromones in the crayfish Orconectes virilis. Journal of Chemical Ecology 11:1695-1711.

Hazlett, B.A. 1994. Alarm responses in the crayfish Orconectes virilis and Orconectes propinquus. Journal of Chemical Ecology 20:1525-1535.

Keller, T.A., M.L. Moy, A.L. Stock, and B.A. Hazlett. 2005. Stream periphyton responses to nutrient enrichment and crayfish reductions. Journal of Freshwater Ecology 20:303-310.

Kerby, J.L., S.P.D. Riley, L.B. Kats, and P. Wilson. 2005. Barriers and flow as limiting factors in the spread of an invasive crayfish (Procambarus clarkii) in southern California streams. Biological Conservation 126:402-409.

Kivivuori, L.A. 1994. Temperature selection behavior of cold-acclimated and warm-acclimated crayfish (Astacus astacus (L)). Journal of Thermal Biology 19:291-297. 
Klocker, C.A., and D.L. Strayer. 2004. Interactions among an invasive crayfish (Orconectes rusticus), a native crayfish (Orconectes limosus), and native bivalves (Sphaeriidae and Unionidae). Northeastern Naturalist 11:167-187.

Layne, J.R., D.L. Claussen, and M.L. Manis. 1987. Effects of acclimation temperature, season, and time of day on the critical thermal maxima and minima of the crayfish Orconectes rusticus. Journal of Thermal Biology 12:183-187.

Lodge, D.M., and A.M. Hill. 1994. Factors governing species composition, population size, and productivity of cool-water crayfish. Nordic Journal of Freshwater Research 69:111-136.

Momot, W.T. 1984. Crayfish production: A reflection of community energetics. Journal of Crustacean Biology 4:35-54.

Mundahl, N.D. 1989. Seasonal and diel changes in thermal tolerance of the crayfish Orconectes rusticus, with evidence for behavioral thermoregulation. Journal of the North American Benthological Society 8:173-179.

Mundahl, N.D., and M.J. Benton. 1990. Aspects of the thermal ecology of the Rusty Crayfish Orconectes rusticus (Girard). Oecologia 82:210-216.

Olden, J.D., J.M. Mccarthy, J.T. Maxted, W.W. Fetzer, and M.J. Vander Zanden. 2006. The rapid spread of Rusty Crayfish (Orconectes rusticus) with observations on native crayfish declines in Wisconsin (USA) over the past 130 years. Biological Invasions 8:1621-1628.

Peck, S.K. 1985. Effects of aggressive interaction on temperature selection by the crayfish, Orconectes virilis. American Midland Naturalist 114:159-167.

Pörtner, H.O. 2002. Climate variations and the physiological basis of temperaturedependent biogeography: Systemic to molecular hierarchy of thermal tolerance in animals. Comparative Biochemistry and Physiology—Part A: Molecular and Integrative Physiology 132:739-761.

Rabeni, C.F. 1992. Trophic linkage between stream Centrarchids and their crayfish prey. Canadian Journal of Fisheries and Aquatic Sciences 49:1714-1721.

Spencer, D.F. 1984. Oxygen consumption by the crayfish Orconectes propinquus (Girard) exposed to aquashade. Bulletin of Environmental Contamination and Toxicology 33:373-378.

Statzner, B., E. Fievet, J.-Y. Champagne, R. Morel, and E. Herouin. 2000. Crayfish as geomorphic agents and ecosystem engineers: Biological behavior affects sand and gravel erosion in experimental streams. Limnology and Oceanography 45:1030-1040.

Stein, R.A. 1977. Selective predation, optimal foraging, and predator-prey interaction between fish and crayfish. Ecology 58:1237-1253.

Taniguchi, Y., F.J. Rahel, D.C. Novinger, and K.G. Geron. 1998. Temperature mediation of competitive interactions among three fish species that replace each other along longitudinal stream gradients. Canadian Journal of Fisheries and Aquatic Sciences 55:1894-1901.

Taylor, C.A., M.L. Warren, J.F. Fitzpatrick, H.H. Hobbs, R.F. Jezerinac, W.L. Pflieger, and H.W. Robinson. 1996. Conservation status of crayfishes of the United States and Canada. Fisheries 21:25-38.

Taylor, R.C. 1984. Thermal preference and temporal distribution in 3 crayfish species. Comparative Biochemistry and Physiology A 77:513-517.

Vannote, R.L., and B.W. Sweeney. 1980. Geographic analysis of thermal equilibria: A conceptual-model for evaluating the effect of natural and modified thermal regimes on aquatic insect communities. American Naturalist 115:667-695. 
Vannote, R.L., G.W. Minshall, W. Cummins, J.R. Sedell, and C.E. Cushing. 1980. The river continuum concept. Canadian Journal Fisheries and Aquatic Science 37:130-137.

Wetzel, J.E., and P.B. Brown. 1993. Growth and survival of juvenile Orconectes virilis and Orconectes immunis at different temperatures. Journal of the World Aquaculture Society 24:339-343.

Whiteley, N.M., E.W. Taylor, and A.J. El Haj. 1997. Seasonal and latitudinal adaptation to temperature in crustaceans. Journal of Thermal Biology 22:419-427.

Whitledge, G.W., and C.F. Rabeni. 2003. Maximum daily consumption and respiration rates at four temperatures for five species of crayfish from Missouri, USA (Decapoda, Orconectes spp.). Crustaceana 75:1119-1132.

Wilson, K.A., J.J. Magnuson, D.M. Lodge, A.M. Hill, T.K. Kratz, W.L. Perry, and T.V. Willis. 2004. A long-term Rusty Crayfish (Orconectes rusticus) invasion: Dispersal patterns and community change in a north temperate lake. Canadian Journal of Fisheries and Aquatic Sciences 61:2255-2266. 
Copyright of Northeastern Naturalist is the property of Humboldt Field Research Institute and its content may not be copied or emailed to multiple sites or posted to a listserv without the copyright holder's express written permission. However, users may print, download, or email articles for individual use. 